\title{
A NEW WAY OF DISSEMINATION IN ANAGALLIS ARVENSIS L. (PRIMULACEAE)
}

\author{
JACEK DROBNIK, BARBARA BACLER \\ Department and Subdepartment of Pharmaceutical Botany and Herbalism, \\ Medical University of Silesia \\ Ostrogórska 30, 41-200 Sosnowiec, Poland \\ e-mail: jacekdr@pro.onet.pl
}

(Received: June 6, 2006. Accepted: September 13, 2006)

\begin{abstract}
Anagallis arvensis L. fruits are globose pyxides. They contain a unique globose columella with 20-30 seeds on its surface. In ripe, open fruits the ball-shaped columella detaches easily and becomes a unique diaspore, which can roll on the ground. This way of dissemination has not been described so far neither in Anagallis nor in other Primulaceae.
\end{abstract}

KEY WORDS: Anagallis arvensis, carpology, dissemination biology, weeds.

\section{DIASPORES AND DISSEMINATION BIOLOGY}

One of the rarely observed adaptations for diaspores dispersal is a structure which provides rolling on the ground or on other surfaces. Such diaspores must be heavy enough, globose and glabrous. Thanks to these characters, when falling onto leaves of other plants or on the surface of the soil, in favourable conditions they can roll some scores of centimetres from the parent plant.

This adaptation of seed structure can be observed among some agricultural weeds, e.g. vetches Vicia angustifolia L. $V$. cracca L. and charlock Sinapis arvensis L. Globose seeds are also produced by some cultivated plants: pea Pisum sativum L. and white mustard S. alba L. (see Beijerinck 1947).

Scarlet pimpernel Anagallis arvensis L. does not produce such seeds. However, it developed a similar dispersal strategy thanks to a peculiar fruit anatomy. It has not been described in details so far. The famous De Jussieu's (1849) handbook of botany was one and only, in which we found a short notice that "seeds of Anagallis are arranged inside the fruit into a ball". The author's original figure contained some inaccuracies, and the text did not explain the dissemination mechanism.

A. arvensis is a small decumbent annual weed met in arable lands, waste lands and in gardens. The stem is thin, up to $40 \mathrm{~cm}$ long. In nodes it produces opposite leaves and solitary small flowers with salmon-red corolla (Stace 1997). Flowering time in Central Europe lasts since June up to October (Kornaś 1963). Plants can be found in fruit for 4 months of the year or even longer. The average seed num- ber per plant is around 900 but a large specimen may yield as many as 1200 seeds (Salisbury 1962; Rao 2000).

Pedicels are slender, $3.0-3.5 \mathrm{~cm}$ long, filiform, and become reflected and rigid at fructification. The fruit is a globose, 3.0-4.0 $\mathrm{mm}$ in diameter, circumscissile capsule, i.e. a pyxide (pyxidium) dehiscing along a transverse, equatorial line. The pericarp (pericarpium) is very thin, membranous, on the average $0.06 \mathrm{~mm}$ thick. On both parts of the fruit there are visible 10 thin vascular bundles. They are located meridionally in regular spaces and go from the receptacle (receptaculum) to the base of the style (stylus) (Fig. 1a). The upper half of the ripe fruit separates as a hemispherical-shaped lid (operculum) together with a persistent style (Fig. 1b). This way a similar cupulate basal half of the fruit remains on the pedicel.

In this persistent part of the pyxide there is embedded a columella. This organ, despite its name, is also ideally globose, like the fruit, and it is contiguous to the inner wall of the pericarp when the pyxide is young. The final size of the columella is 2.2 to $2.9 \mathrm{~mm}$ in diameter when the ripe pyxide opens. Since this moment tissues of the columella start to dehydrate and the whole organ contracts slightly.

The spherical surface of a mature columella is covered with numerous pits in which seeds are formed (Fig. 1c). The seed shape is a frustum of a pentagonal or hexagonal pyramid with rounded lateral edges. Sometimes its shape resembles rather a frustum of a cone (Fig. 1e). Dimensions of ripe, blackish-brown seeds are 0.5-0.8 (-1.3) × 0.7-1.1 (-1.6) mm (Kornaś 1963; Kulpa 1974).

Each seed is connected to the columella with a very short funiculus in the bottom of the pit. The orientation of 


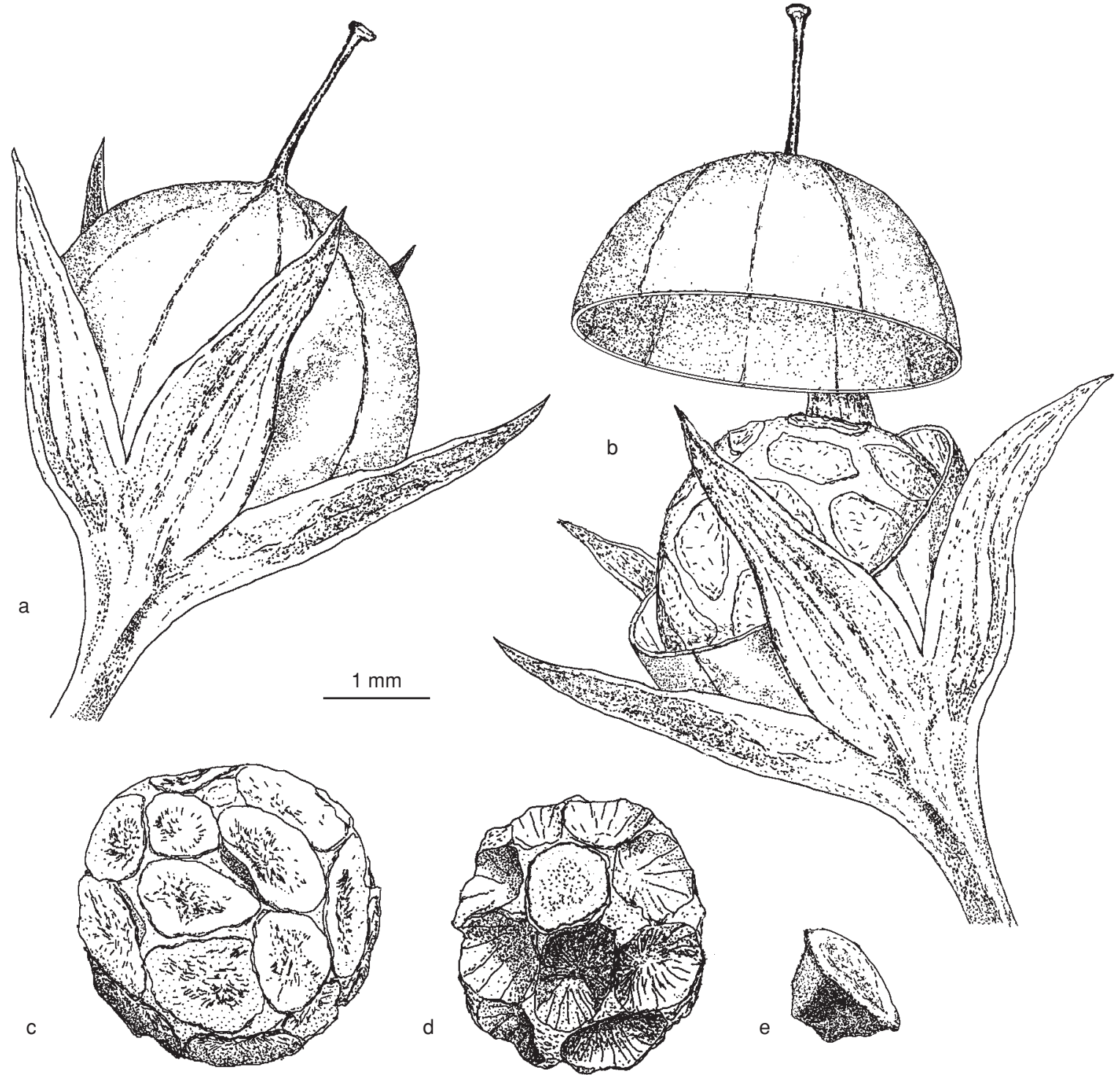

Fig. 1. Fruit of Anagallis arvensis: a - almost ripe pyxide; $\mathrm{b}$ - open pyxide with the fleshy globose columella inside; $\mathrm{c}-\mathrm{dehydrated}$ columella released from the fruit, with seeds; d - columella with the last seed; e - seed (drawn by J. Drobnik)

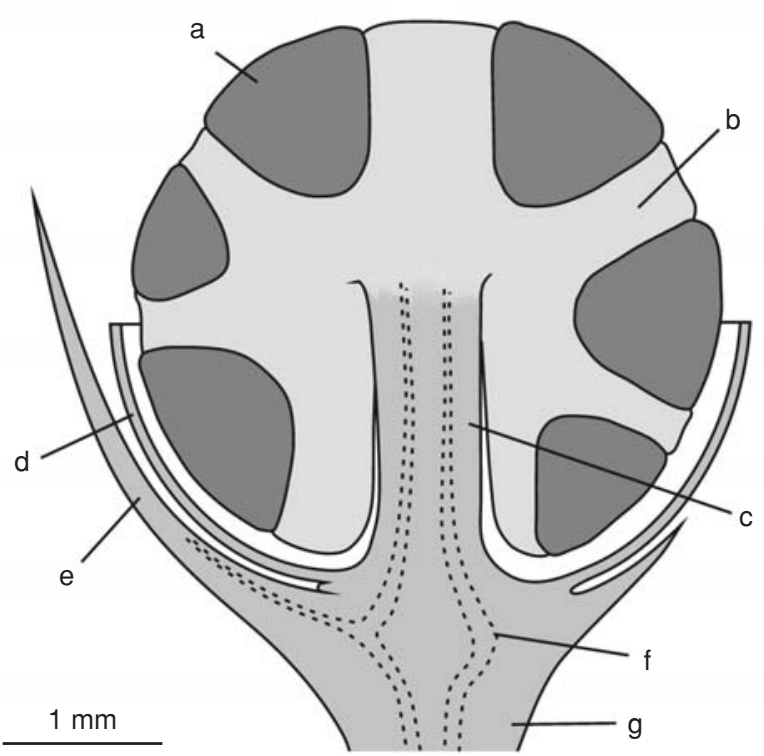

Fig. 2. Schematic longitudinal section of an open fruit of Anagallis arvensis: $\mathrm{a}$ - seed; $\mathrm{b}$ - columella; $\mathrm{c}$ - filamentous part of the columella; $\mathrm{d}$ - pericarp; e - sepal; f - vascular bundle; g - pedicel (drawn by J. Drobnik) the seeds is so their broadest parts (i.e. bases of pyramids) build the spherical surface of the whole organ. A single columella bears 20-30 seeds (Fig. 1c).

The ovary is unilocular and the columella is attached only to the bottom of the locule, thus the placentation type is free-central. The columella is connected to the ovary with a thin filamentous organ in which there are usually 8 vascular bundles. This minute filamentous fastening structure is completely submerged in the columella tissues. It is approximately as long as the radius of the columella and $0.5 \mathrm{~mm}$ thick (Fig. 2).

In a ripe open pyxide the columella easily detaches and drops out from the cupulate remnant of the fruit. The columella rolls on the ground while seeds may release from its pits (Fig. 1d) or remain still attached. Bases of the seeds in a contracted columella slightly protrude from its surface, so they can fall off easily.

\section{CONCLUSIONS}

The described mechanism is a way to deposit Anagallis arvensis seeds in a longer distance from the parent plant 
specimen. While normal vegetation of this weed on arable or waste lands, columellas happen to remain in open fruits. However, during agronomic works, the loose columellas may appear as a common admixture among other plants diaspores.

Similar structure of fruit is observed in chaffweed Anagallis minima (L.) K. Krause (see: Hegi 1966), so one can expect the same dispersal mechanism.

\section{LITERATURE CITED}

BEIJERINCK W. 1947. Zadenatlas der Nederlandsche flora ten behoeve van de botanie, paleontologie, bodemcultur en warenkennis, Biologisch Station te Wijster, H. Veenman and Zonen, Wageningen. (in Dutch)
DE JUSSIEU A. 1849. Wykład początków botaniki. Lecture on basic botany: Tytus Chałubiński. Warszawa, p. 423. (in Polish) HEGI G. 1966. Illustrierte Flora von Mitteleuropa. Verlag Paul Parey, Berlin-Hamburg, 5 (3): 1868-1874.

KORNAŚ J. 1963. Anagallis L., kurzyślad. In: Flora polska. Rośliny naczyniowe Polski i ziem ościennych [The Polish flora. Vascular plants of Poland and adjacent lands], Pawłowski B. (ed.). PWN, Warszawa-Kraków, 10: 47-51. (in Polish)

KULPA W. 1974. Nasionoznawstwo chwastów [Carpology of weeds]. Ed. 2. PWRiL, Warszawa, pp. 197-198. (in Polish)

RAO V.S. 2000. Principles of Weed Science. Ed. 2. Science Publishers, Inc. USA, pp. 413-414.

SALISBURY E. 1962. The Biology of Garden Weeds. Part 1. J. Royal Hort. Soc. 87: 338-350, 390-404.

STACE C. 1997. New Flora of the British Isles, ed. 2. Cambridge University Press, Cambridge, pp. 301-302. 